\title{
Conservation Status of Indian Pandanaceae
}

\author{
Rahul L. Zanan, Altafhusain B. Nadaf* \\ Department of Botany, University of Pune, Pune, India. \\ Email: *abnadaf@unipune.ac.in \\ Received April 10 $0^{\text {th }}, 2013$; revised May $11^{\text {th }}, 2013$; accepted June $3^{\text {rd }}, 2013$ \\ Copyright (C) 2013 Rahul L. Zanan, Altafhusain B. Nadaf. This is an open access article distributed under the Creative Commons \\ Attribution License, which permits unrestricted use, distribution, and reproduction in any medium, provided the original work is \\ properly cited.
}

\begin{abstract}
The Pandanaceae in India are represented by three genera: Pandanus Parkinson (distributed in South and Northeast India and Andaman and Nicobar Islands), Benstonea Callm \& Buerki (distributed in South and Northeast India) and Freycinetia Gaudich from Andaman and Nicobar Islands. A detailed survey was carried out from November 2007 to February 2013 along the Peninsular India, North eastern India and Andaman Islands and conservation status of Indian Pandanaceae species was determined following IUCN Red List Categories and Criteria (2001). The assessment indicated that, among the 19 Indian Pandanaceae members, 6 species are falling under threatened category. P. palakkadensis and $P$. mangalorensis falls under Critically Endangered, $P$. unguifer and $P$. martinianus under endangered and $P$. diversus and $B$. thwaitesii under vulnerable category. $P$. furcatus, $P$. unipapillatus, $P$. odorifer, $P$. kaida, $P$. leram, $P$. nepalensis and $B$. foetida, F. sumatrana and F. rigidifolia fall under Least Concern category. P. emarginatus under Data Deficient category and $P$. amaryllifolius, $P$. sanderi and $P$. dubius as exotic species. Based on our study, we recommend 6 threatened species to include in the IUCN Red List.
\end{abstract}

Keywords: Indian Pandanaceae; Conservation Status; IUCN Red List Categories and Criteria

\section{Introduction}

At global level, India shares $2.4 \%$ of the land area with about $7 \%-8 \%$ of total recorded species of the world, in which about $33 \%$ of the flowering plants are recorded as endemic [1]. The most obvious endemic areas within the country are the Western Ghats, Northwest Himalayas and Andaman and Nicobar Islands. Western Ghats and North East India are regarded as a high priority for conservation. Application of the IUCN Red List criteria, a widely recognized tool for identifying threatened species, offers a powerful method to identify priority sites for protection by providing information on the conservation status of species in the wild [2]. Western Ghats is one of the richest centres of endemism; it has 490 arborescent taxa, of which as many as 308 are endemic. About 1500 endemic dicotyledonous plant species and 245 orchid species recorded in which 112 species are endemic. Nearly 235 species of endemic flowering plants are considered endangered [3]. From whole Eastern Himalayas estimated 9000 plant species, in which 3500 (39\%) are endemic and from Indian Himalayas, about 5800 plant species are

"Corresponding author. recorded (2000 (36\%) endemic) with about 55 flowering plants are rare [3]. Andaman and Nicobar islands are being the hotspot of biological diversity; over 2500 Angiosperm species were reported from these islands of which about 246 are endemic to the islands [4].

The Pandanaceae in India are represented by three genera: Pandanus Parkinson (distributed in South and Northeast India and Andaman and Nicobar Islands), Benstonea Callm \& Buerki (distributed in South and Northeast India) and Freycinetia Gaudich from Andaman and Nicobar Islands [5]. Callmander et al. [6] assessed Malagasy Pandanaceae for its conservation status based on application of the methodologies proposed by Schatz et al. [7], Willis et al. [8], a $3 \times 3 \mathrm{~km}$ grid cell size and a $3 \times$ $3 \mathrm{~km}$ grid incorporating field observations. From these four methods, they suggested that $3 \times 3 \mathrm{~km}$ grid with field observations is the best method for evaluating Pandanaceae species. In the present report, Indian Pandanaceae species have been assessed for their biogeographic distribution and conservation status following the IUCN categories and criteria [9] using the methodology suggested by Callmander et al. [6]. Moreover, conservation measures for the threatened species have been suggested. 


\section{Materials and Methods}

\subsection{Survey and Identification of Pandanaceae Genera and Species}

A detailed survey was carried out from November 2007 to February 2013 along the Peninsular India, North eastern India and Andaman Islands to locate Pandanaceae members. During the survey, information pertaining to longitude, latitude and altitude of each locality was recorded using global positioning system (Magellan GPS 315-Taiwan). The collected Pandanus species were identified and authenticated at the Botanical Survey of India, Western circle, Pune and Botanical Survey of India, Kolkata, India and dried herbarium specimens are deposited. The new records were confirmed by Dr. Martin W. Callmander, Assistant curator and technical advisor for the Conservation and Research Program in Antananarivo, Madagascar, Missouri Botanical Garden, USA and scientific collaborator for the Conservatoire et Jardin botaniquesde la Ville de Genève, Switzerland. Seedlings of the collected species are maintained at the Botanical garden of Department of Botany, University of Pune, Pune, India $\left(18^{\circ} 31^{\prime} 96^{\prime \prime} \mathrm{N}\right.$ longitude, $73^{\circ} 49^{\prime} 49^{\prime \prime} \mathrm{E}$ latitude and $651 \mathrm{~m}$ elevation).

\subsection{Assessment of Conservation Status}

In order to assess conservation status of Indian Pandanus species, we conducted threat assessment exercise following IUCN Red List Categories and Criteria [9] during 2007-2013. The IUCN status of the threatened species has been determined following the methodology suggested by Callmander et al. [6]. The details are as follows. Based on a survey, localities for respective species were identified, a grid of $3 \times 3 \mathrm{~km}$ was placed, and the numbers of populations and subpopulations were determined. Based on this data, extent of occurrence (EOO, minimum convex polygon containing all points of occurrence) and area of occupancy (AOO, area estimated by superimposing a grid onto occurrence points and calculating the cumulative area of cells occupied by a species) were determined. The current situation for lived plants depends on habitat degradation and destruction of primary vegetation outside the protected areas and loss of primary vegetation within protected areas. For species habitat disturbance, the calculation of EOO and AOO were estimated and such species were evaluated based on direct field observations, indicating those known to be in continuing decline so that the Red List criteria can be applied.

\section{Results and Discussion}

A summary of the Indian Pandanaceae with respect to their biogeographic distribution and conservation status is presented below.

\subsection{Distribution and Conservation Status of Benstonea Species}

3.1.1. Benstonea thwaitesii (Martelli) Callm. \& Buerki Benstonea thwaitesii is distributed in deep forests of the Western Ghats covering Maharashtra, Goa, Karnataka, Kerala, and Tamil Nadu states of India. It has an extent of occurrence (EOO) is $<20,000 \mathrm{~km}^{2}$, an area of occupancy (AOO) is $<2000 \mathrm{~km}^{2}$, and comprises up to 25 known fragmented populations, the maximum of which are found in sacred groves of Maharashtra, Goa, and some are found in reserved forests of Karnataka and Kerala. Based on IUCN Red List criteria [5,9], we assign as vulnerable category (VU) (VU B1ab [i,ii,iii] + B2ab [i,ii,iii]). (Table 1, Figure 1(F))

\subsubsection{Benstonea foetida (Roxb.) Callm. \& Buerki}

Benstonea foetida is distributed in conserved forest regions of Karnataka and Kerala states of Southern India, East Coast of West Bengal and intercostals of Bihar, Jharkhand and West Bengal. According to IUCN Red List Categories and Criteria [9], this species is assigned under the Least Concern (LC) category [5] (Table 1).

\subsection{Distribution and Conservation Status of Pandanus Species}

\subsubsection{Pandanus odorifer (Forssk.) Kuntz.}

In India, Pandanus odorifer is one of the dominant species found in coastal regions of India. It is distributed in open forest having warm humid conditions; Western Ghats (Maharashtra, Goa, Karnataka, and Kerala), Eastern Coastal belt (Tamil Nadu, Andhra Pradesh, Orissa, and West Bengal) [5] and coastal regions of Andaman and Nicobar Islands. Based on IUCN Red List criteria [9] we assigned this species under Least Concern (LC) category (Table 1).

\subsubsection{Pandanus kaida Kurz.}

Pandanus kaida is abundantly distributed in open forests of Goa, Karnataka, Kerala and Tamil Nadu states of Southern India [5]. According to IUCN Red List categories and criteria [9], we assigned this species under the Least Concern (LC) category (Table 1).

\subsubsection{Pandanus furcatus Roxb.}

Pandanus furcatus is predominantly grows in Maharashtra, Goa, Karnataka and Kerala states of Southern India. As per the IUCN Red List Categories and Criteria [9], the species fall under the Least Concern (LC) category [5] (Table 1).

\subsubsection{Pandanus unipapillatus Dennst.}

Pandanus unipapillatus is endemic to Southern India. It is predominantly known in Western Ghats (Maharashtra, 
Table 1. Conservation status of Indian Pandanaceae.

\begin{tabular}{|c|c|}
\hline Conservation categories ${ }^{*}$ & Genera and species \\
\hline Extinct in the Wild (EW) & $\begin{array}{l}\text { Pandanus amaryllifolius Roxb. } \\
\text { Pandanus dubius Spreng. } \\
\text { Pandanus sanderi Sander }\end{array}$ \\
\hline Critically Endangered (CR) & $\begin{array}{l}\text { Pandanus palakkadensis Nadaf, Zanan } \\
\text { \& Wakte } \\
\text { Pandanus mangalorensis Nadaf } \\
\text { \& Zanan }\end{array}$ \\
\hline Endangered (EN) & $\begin{array}{l}\text { Pandanus unguifer Hook. f. } \\
\text { Pandanus martinianus Nadaf \& Zanan } \\
\text { Pandanus diversus St. John. }\end{array}$ \\
\hline Vulnerable (VU) & $\begin{array}{l}\text { Benstonea thwaitesii (Martelli) Callm. } \\
\& \text { Buerki }\end{array}$ \\
\hline Least Concern (LC) & $\begin{array}{l}\text { Pandanus furcatus Roxb. } \\
\text { Pandanus unipapillatus Dennst. } \\
\text { Pandanus odorifer (Forssk.) Kuntz. } \\
\text { Pandanus kaida Kurz. } \\
\text { Pandanus leram Jones. } \\
\text { Pandanus nepalensis St. John. } \\
\text { Benstonea foetida (Roxb.) Callm. } \\
\text { \& Buerki } \\
\text { Freycinetia sumatrana Hemsley } \\
\text { Freycinetia rigidifolia Hemsley }\end{array}$ \\
\hline Data Deficient (DD) & Pandanus emarginatus St. John. \\
\hline
\end{tabular}

"based on IUCN Red list criteria (2001).

Goa, Karnataka, and Kerala). According to the IUCN Red List Categories and Criteria [9], the species is categorized under the Least Concern (LC) category [5] (Table 1).

\subsubsection{Pandanus Palakkadensis Nadaf, Zanan \& Wakte}

Pandanus palakkadensis is endemic to type locality from the Kerala state of Southern India [10]. It is restricted to the type locality and, following the IUCN Red List Categories and Criteria [9], the species is given a preliminary conservation assessment of Critically Endangered (CR 2ab [i,ii,iii,iv]) (Table 1, Figure 1(A)). The locality is affected by shifting cultivation practices and is also used for the rearing of ducks for which plants are being removed. Hence, the species demands urgent need of conservation [10].

\subsubsection{Pandanus mangalorensis Nadaf \& Zanan}

Pandanus mangalorensis is endemic to type locality from the Karnataka state of Southern India. The type locality is influenced by industrial activities and road constructions, and thus urgently demands conservation [11]. According to IUCN Red List Categories and Criteria [9] P. mangalorensis is assigned to Critically Endangered (CR B1ab [i,ii,iii] + B2ab [i,ii,iii $])$, with an EOO of $>100 \mathrm{~km} \mathrm{2}$, an AOO of $>10 \mathrm{~km}^{2}$ (Table 1, Figure 1(D)).

\subsubsection{Pandanus nepalensis St. John.}

Pandanus nepalensis is distributed is abundantly distributed in the Eastern Himalayan region in dense forest of cold highland areas from Darjeeling district of upper West Bengal and South Sikkim districts of Central Himalaya. Based on distribution pattern and area, this species qualifies for the Least Concern (LC) category [5,9] (Table 1).

\subsubsection{Pandanus emarginatus St. John.}

Pandanus emarginatus is endemic to India [12] and is distributed in Bhalukpong, West Kameng district of Arunachal Pradesh of Eastern Himalaya. Due to the lack of data, we have assigned this species under the Data Deficient category (DD) (Table 1).

\subsubsection{Pandanus diversus St. John.}

Pandanus diversus is endemic to India [12] and is dis-
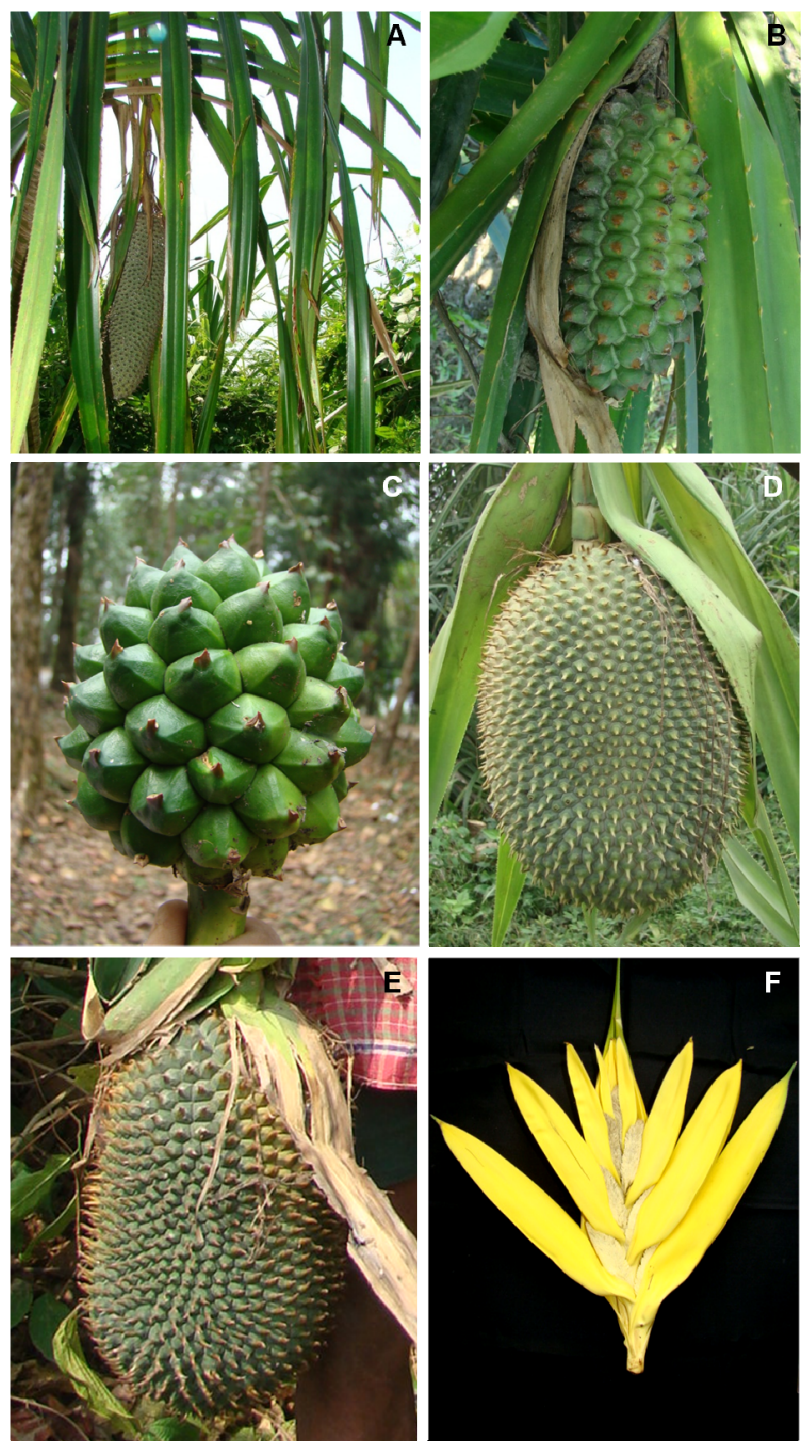

Figure 1. Threatened Indian Pandanaceae members: (A) Pandanus palakkadensis; (B) Pandanus martinianus; (C) Pandanus unguifer; (D) Pandanus mangalorensis; (E) Pandanus diversus; (F) Benstonea thwaitesii. 
tributed in Silchar district, Assam state of North East Hills with an extent of occurrence (EOO) of $100 \mathrm{~km}^{2}$ and an area of occupancy (AOO) of ca. $20 \mathrm{~km}^{2}$. This species comprises six known subpopulations, two of which are located in deep forest areas of Koyla Godam village in the Silchar district and near the tea gardens of Dalu village, Silchar district. Based on IUCN Red List criteria [9], we have assigned the status of Vulnerable (VU D2), and therefore the species is considered to be facing high risk of extinction [5] (Table 1, Figure 1(E)).

\subsubsection{Pandanus leram Jones.}

Pandanus leram is distributed from the Andaman and Nicobar Islands. It is one of the dominant plant species in Andaman and Nicobar Islands. The single individual of the male species is cultivated in the Experimental Botanical Garden, Botanical Survey of India, Yercaud, Salem district, Tamil Nadu [5]. Based on IUCN Red List Categories and Criteria [9] we assigned this species under Least Concern (LC) category (Table 1).

\subsubsection{Pandanus unguifer Hook. f.}

Pandanus unguifer is distributed in South Sikkim districts of Central Himalaya and Darjeeling district of upper West Bengal. The species has an extent of occurrence (EOO) $<100 \mathrm{~km}^{2}$, an area of occupancy (AOO) $<15 \mathrm{~km}^{2}$, and comprises up to five known subpopulations, in which two locations are found in a conserved forest (Rambi Bazar, Darjeeling district) and others are near Cinchona Factory and in Cinchona plantation of Mungpoo village, Darjeeling district. As per the IUCN Red List criteria [9], the species is assigned to Endangered category (EN B1ab [i,ii,iii] + B2ab [i,ii,iii]) [5] (Table 1, Figure 1(C)).

\subsubsection{Pandanus martinianus Nadaf \& Zanan}

Pandanus martinianus is endemic to India [13]. It is distributed in foothills of open forests in West Siang District of Arunachal Pradesh and Dhemaji District of Assam. It has an extent of occurrence (EOO) of ca. $300 \mathrm{~km}^{2}$, an area of occupancy (AOO) of $90 \mathrm{~km}^{2}$ and comprises up to ten known subpopulations, three of which are found in a conserved forest (Arunachal Pradesh). P. martinianusshould be considered as Endangered [EN B1ab (i,ii,iii) + B2ab (i,ii,iii)] according to IUCN Red List Categories and Criteria [5,9,13] (Table 1, Figure 1(B)).

\subsubsection{Pandanus dubius Spreng.}

Pandanus dubius is cultivated as an exotic species in gardens of Kerala and Karnataka. It is reported to be distributed from Andaman and Nicobar Islands to West Pacific and indigenous to most of Malanesia and Polynesia; aboriginal introduction to Micronesia [14] but we didn't locate this species in Andaman and Islands. Since it is an exotic species, its conservation status is not determined
(Table 1).

\subsubsection{Pandanus amaryllifolius Roxb.}

Pandanus amaryllifolius is also an exotic species popularly cultivated in kitchen gardens in that states of Gujarat, Maharashtra, Goa, Karnataka, Kerala, Tamil Nadu, Orissa and West Bengal [15] for their fragrant leaves. It is originated in the region of the Moluccas Islands and has spread across the tropical region of Asia [16]. Then it widely distributed in different tropical Peninsular countries, including Sri Lanka, Thailand, Southern India, Malaysia, Indonesia, Singapore, Vietnam, New Guinea, Taiwan, and the Philippines [15-17]. The conservation status is not determined due to its exotic origin (Table 1).

\subsubsection{Pandanus sanderi Sander}

Pandanus sanderi is also an exotic species popularly cultivated in gardens for its variegated leaves. Its conservation status is also not determined (Table 1).

\subsection{Distribution and Conservation Status of Freycinetia Species}

\subsubsection{Freycinetia rigidifolia Hemsley}

Freycinetia rigidifolia is commonly grown as a climber in deep forests of Andaman and Nicobar Islands [18]. According to IUCN Red List Categories and Criteria [9] we assigned this species under Least Concern (LC) category (Table 1).

\subsubsection{Freycinetia sumatrana Hemsley}

In India, Freycinetia sumatrana is distributed only in Andaman and Nicobar Islands [18], found commonly growing in deep forests, as climber on large trees. According to IUCN Red List Categories and Criteria [9] we assigned this species under Least Concern (LC) category (Table 1).

The summary of conservation status of Indian Pandanaceae is depicted in Table 1. Our analyses showed that, among the 19 Indian Pandanaceae species, 6 species are falling under threatened category, and these therefore represent highest priorities for Pandanaceae conservation. The high species richness and endemism occur in Southern and North Eastern India; in Southern India, 8 native species are grown in which 3 species falls under threatened and in North Eastern India, 6 native species 3 are under threatened category. In Andaman and Nicobar Islands 2 Pandanus and 2 Freycinetia species were found to be not falling under threatened categories. P. palakkadensis and $P$. mangalorensis fall under Critically Endangered, $P$. unguifer and $P$. martinianus under Endangered and $P$. diversus and $B$. thwaitesii under Vulnerable category. P. furcatus, P. unipapillatus, $P$. odorifer, $P$. kaida, P. leram, P. nepalensis and B. foetida, F. suma- 
trana and F. rigidifolia fall under Least Concern category. $P$. emarginatus under Data Deficient category and $P$. amaryllifolius, $P$. sanderi and $P$. dubius as exotic species. Based on this study, we recommend 6 threatened species to include in the IUCN Red List.

\subsection{Conservation Measures for Threatened Species}

The present detailed analysis is an important contribution towards identifying threatened Pandanaceae species. Further the study demands urgent steps to conserve these threatened Pandanaceae members to ensure their continued survival and sustenance. To conserve the threatened Pandanaceae species following measures are recommended: Improved protection efforts should be made and a landscape approach needs to be followed for conservation. In addition, in situ approach through establishment of protected area network with appropriate management practices, corridors to link fragments, restoration of degraded habitats within and outside protected areas can be attempted. Ex situ approach through collection of germpalsm and maintaining in botanical gardens, in vitro regeneration, deposition of DNA in DNA bank is also one of the measures to conserve the germplasm. In addition, reduction of biotic (anthropogenic) pressure by cultivating threatened species in other localities followed by regular population-habitat viability and risk assessment can be done. Establishment of species preservation plots, Increased Public Awareness through educational programs, incentive programs, and volunteer monitoring programs.

As a part of ex situ conservation, the seedlings of threatened Pandanaceae members are maintained at the botanical garden of Department of Botany, University of Pune, Pune, India. The genetic resources play an important role in environmental protection, sustainable management, and conservation of biodiversity. Conservation of genetic resources not only prevents extinction of a species but also reduction of gene pool and loss of genes and genotypes [19]. From this view point, the study highlights the urgent conservation need for the threatened Indian Pandanaceae members.

\section{Acknowledgements}

The authors thank Dr. Martin W. Callmander, Assistant Curator, Missouri Botanical Garden, Saint-Louis, USA, and Conservatoire and Jardin botaniquesde la Ville deGenève, Switzerland for carefully reviewing the threat analyses and suggesting useful changes. This work has been carried out through the financial assistance from the Board of College and University Development (BCUD), University of Pune, Pune, India.

\section{REFERENCES}

[1] T. N. Khoshoo, "India Needs a National Biodiversity Conservation Board," Current Science, Vol. 71, No. 7, 1996, pp. 506-513.

[2] A. S. L. Rodrigues, J. D. Pilgrim, J. F. Lamoreux, M. Hoffman and T. M. Brooks, "The Value of the IUCN Red List for Conservation," Trends in Ecology \& Evolution, Vol. 21, No. 2, 2006, pp. 71-76. doi:10.1016/j.tree.2005.10.010

[3] MoEF, "State of Environment Report India-2009" Environmental Information System (ENVIS), Ministry of Environment \& Forests Government of India, 2009, pp. 50-71.

[4] N. P. Balakrishnan and J. L. Ellis, "Andaman and Nicobar Islands," In: P. K. Hajra, B. D. Sharma, M. Sanjappa and A. R. K. Sastry, Eds., Flora of India Introductory Volume, Part 1, Botanical Survey of India, Calcutta, 1996, pp. 523-538.

[5] A. B. Nadaf and R. L. Zanan, "Indian Pandanaceae-An Overview," Springer, Germany, 2012. doi:10.1007/978-81-322-0753-5

[6] M. W. Callmander, G. E. Schatz, P. P. Lowry II, M. O. Laivao, J. Raharimampionona, S. Andriambololonera, T. Raminosoa and T. Consiglio, "Application of IUCN Red List Criteria and Assessment of Priority Areas for Plant Conservation in Madagascar: Rare and Threatened Pandanaceae Indicate New Sites in Need of Protection," Oryx, Vol. 41, No. 2, 2007, pp. 168-176. doi:10.1017/S0030605307001731

[7] G. E. Schatz, C. Birkinshaw, P. P. Lowry II, F. Randriantafiḱa and F. Ratovoson, "The Endemic Plant Families of Madagascar Project: Integrating Taxonomy and Conservation," In: W. R. Lourenço and S. M. Goodman, Eds., Diversité et Endémisme à Madagascar, Mémoires de la Société Biogéographie, Paris, 2000, pp. 11-24.

[8] F. Willis, J. Moat and A. Paton, "Defining a Role Forherbarium Data in Red List Assessments: A Case Study of Plectranthus from Eastern and Southern Tropical Africa," Biodiversity and Conservation, Vol. 12, No. 7, 2003, pp. 1537-1552. doi:10.1023/A:1023679329093

[9] IUCN, "IUCN Red List Categories and Criteria: Version 3.1," IUCN Species Survival Commission, IUCN, Gland/ Switzerland/Cambridge, 2001, pp. ii +33 .

[10] A. B. Nadaf, R. L. Zanan and K. V. Wakte, "A New Endemic Species of Pandanaceae from India: Pandanus palakkadensis," Kew Bulletin, Vol. 66, No. 1, 2011, pp. 1-5. doi:10.1007/s12225-011-9265-0

[11] R. L. Zanan and A. B. Nadaf, "Pandanus mangalorensis: A New Species of Pandanaceae from Southern India," Kew Bulletin, Vol. 67, No. 3, 2012, 555-559. doi:10.1007/s12225-012-9366-4

[12] H. St. John, "The Indian Species of Pandanus (Section Rykia)," The Botanical Magazine Tokyo, Vol. 85, No. 4, 1972, pp. 241-262. doi:10.1007/BF02490171

[13] R. L. Zanan and A. B. Nadaf "Pandanus martinianus (Pandanaceae), a New Species Endemic from North Eastern Region of India," Phytotaxa, Vol. 73, 2012, pp. 1-7.

[14] K. M. Wilkinson and C. R. Elevitch, "Nontimber Forest 
Products for Pacific Islands: An Introductory Guide for producers," In: C. R. Elevitch and K. M. Wilkinson, Eds., "Agroforestry guides for Pacific Islands," Permanent Agriculture Resources, Holualoa, 2000, pp. 72-98.

[15] K. V. Wakte, A. B. Nadaf, R. J. Thengane and N. Jawali, "Pandanus amaryllifolius Roxb. Cultivated as a Spice in Coastal Regions of India," Genetic Resources and Crop Evolution, Vol. 56, No. 5, 2009, pp. 735-740. doi:10.1007/s10722-009-9431-5

[16] B. C. Stone, "Studies in Malesian Pandanaceae XVII. On the Taxonomy of 'Pandan Wangi': A Pandanus Cultivar with Scented Leaves," Economic Botany, Vol. 32, No. 3, 1978, pp. 285-293. doi:10.1007/BF02864702

[17] P. N. Ravindran and I. Balachandran, "Underutilized Medicinal Species-III," Spice India, Vol. 18, No. 2, 2005,
16-24.

[18] B. C. Stone, "Materials for a Monograph of Freycinetia Gaud. (Pandanaceae) VII. Species of Ceylon and the Andaman and Nicobar Islands," Webbia, Vol. 23, No. 2, 1969 , pp. 591-599. doi:10.1080/00837792.1969.10669897

[19] N. H. Nghia, "Conservation of Forest Genetic Resources in Vietnam with Reference to Endangered Tree Species," Proceedings of the South East Asian Moving Workshop on Conservation, Management and Utilization of Forest Genetic Resources, Thailand, 25 February-10 March 2001. http://www.fao.org/DOCREP/005/AC648E/AC648E00.ht $\mathrm{m}$ 